\title{
Estonian Curriculum: Becoming Independent
}

\author{
Ene-Silvia Sarv and Vadim Rõuk
}

\begin{abstract}
Curriculum reform was part of educational reform that began in Estonia in 1987. Analysis of archival, legislative, and textual materials, including earlier research papers and interviews of key persons was completed primarily through content analysis. The lack of curriculum specialists in Soviet republics required use of all existing intellectual potential for the creation of an original, modern, and national curriculum based on local traditions. Parallel to attempts to create an independent, social-constructivist curriculum in Estonia in the early 1990s, there was a desire to preserve "best traditions" from the Soviet programmes and methodology. Confrontation between the two educational paradigms manifested both at the organisational level and in the perception of actors. Renouncing Soviet ideology and traditions in subject programmes and development of comprehensive curriculum was a crucial turning point towards independence in education and educational thinking in Estonia.
\end{abstract}

Keywords: reform of education, Estonian national curriculum, personal experience

\section{Introduction}

Curriculum development is undoubtedly at the heart of school and educational reform. Yet, school and educational reform was/is an important aspect of securing national identity and sustainability. The development of Estonian national school curricula from 1987 until after the rebirth of the state in 1991 reflects paradigmatic theoretical and inconsistencies. The periods 1987-1991 and 1992-1996 differ radically in a historical-political-economic view. The first was similar to the National Awakening and quest for sovereignty (1850-1918), including education. ${ }^{1}$ This period was characterised by intense participation and processes, resulting in the emergence and amplification of different ideals. Our study described the transition period ${ }^{2}$ from the Soviet model to a new state of culture, economy, education, and national curricula.

1 J. Orn, 'Sada aastat Kasvatuse ja Hariduse ilmumisest' [One hundred years since the publication of the Education and Upbringing magazine], Õpetajate Leht [The Teachers' Newspaper], 27 January 2017. Available: http://opleht.ee/2017/01/sada-aastat-kasvatuse-ja-hariduseilmumisest/ (accessed 19.02.20).

2 M. Lauristin, P. Vihalemm, 'Recent Historical Developments in Estonia: Three Stages of Transition (1987-1997), in M. Lauristin et al. (eds.) Return to the Western World. Cultural and Political Perspectives on Estonian Post-Communist Transition, Tartu, Tartu University Press, 1997, pp. 73-127. 
One of first attempts to analyse processes and ideas of educational renewal in a contemporary context was published in two collections of theoretical articles and projects in 1991. ${ }^{3}$ In Some thoughts about 'the correct educational ideology,' Peeter Kreitzberg stated that globally, we can see "the continuing decline of the so-called scientific curriculum, which in a sense reflects the consequences of the reversal of the industrial revolution, of the domination of a positivist think-tank in the wider perspective of the design of education, including general education and curricula." In principle, this "rejection" was also reflected in curriculum development in Estonia and in several other former Soviet republics, including Russia, in the 1980s and early 1990s. ${ }^{5}$

The renewal of education and the process of curriculum development in Estonia is discussed in several doctoral and master's theses ${ }^{6}$ and overviews ${ }^{7}$

3 E. Grauberg (ed.), Hariduse kavandamise metodoloogilistest ja sotsiaal-majanduslikest lähtealustest [Methodological and socio-economic background to educational planning], Tallinn, EV Haridusministeerum, 1991; E. Grauberg (ed.), Hariduse kavandamise kultuur-filosoofilistest lähtealustest [On cultural-philosophical background of educational planning], Tallinn, EV Haridusministeerium, Eesti Õppekirjanduse keskus, 1991.

${ }^{4}$ P. Kreitzberg, 'Mõned mõtted seoses "õige haridusideoloogiaga' [Some thoughts about "the right educational ideology"], in E. Grauberg (ed.), Hariduse kavandamise metodoloogilistest ja sotsiaalmajanduslikest lähtealustest. [Methodological and socio-economic background to educational planning], Tallinn, EV Haridusministeerium, Eesti Õppekirjanduse keskus, 1991, p. 8.

5 E. D. Dnjeprov, Shkolnaya reforma mezhdu "vchera" $i$ "zavtra" [School reform between "yesterday" and "tomorrow"], Moskva, RAO FIPO MORF, 1996.

6 P. Kreitzberg, The Legitimation of Educational Aims: Paradigms and Metaphors, Lund, Lund University, 1993; P. Kreitzberg, 'Õppekava koostamine on kompromisside otsimise kunst' [Creating a curriculum is the art of compromising], Riigikogu Toimetised [Journal of the Estonian Parliament], no. 14, 2006. Available: http://www.riigikogu.ee/rva/toimetised/rito14/ artiklid/05kreitzberg.htm (accessed 15.05.08); V. Nagel, Hariduspoliitika ja üldhariduskorraldus Eestis aastatel 1940-1991 [Education policy and general education organisation in Estonia in the years 1940-1991], Tallinna Ülikool, 2006; E. Veenpere, Eesti haridusuuendus 1987-1998: probleeme ja võimalusi [Estonia - educational renewal 1987-1998: problems and opportunities], Tartu Ülikool, 1999.

7 E.g., V. Ruus, E.-S. Sarv, 'Changes in Estonian Curricula (1987-1999) and Some Thoughts on the Future, in B. T. Beck, A. Mays (eds.), Challenge and Change in Education: the Experience of the Baltic States in the 1990's, New York, Nova Science Publishers, 2000, pp. 141-152; V. Rõuk, 'Curriculum History and Planning: Theoretical Framework and Some Guidelines of Its Development in Estonia, 1987-1996,' Acta Paedagogica Vilnensia, no. 31, 2013, pp. 19-29. Available: http://www.zurnalai.vu.lt/acta-paedagogica-vilnensia/article/viewFile/2518/1728 (accessed 24.10.18); M. Oja. Muutused üldhariduskooli ajalooõpetuses alates 1987. aastast nõukogulikust tänapäevaseks [Changes in history teaching in general education since 1987 from Soviet to modern], Tallinn, Tallinna Ülikool, 2016; U. Läänemets, Content Development for Estonian General Comprehensive Schools: Context, Curricula and School Practice 1991-2016. In: V. Lubkina; S. Usca (eds.). Education Reform in Comprehensive School: Education Content Research and Implementation Problems, Rezekne, Rezekne Academy of Technologies, 2017, pp. 53-61, Available: http://journals.rta.lv/index.php/PSPI/article/view/2182 (accessed 20.02.20); U. Läänemets, About the Evolution of the Content of Education and School Curricula in Estonia, Tallinn, Jaan Tõnissoni Instituut, 1995; V.-R. Ruus, 'Eesti õppekavareform 1987-2002' [Curriculum reform 1987-2002 in Estonia], in A. Liimets, V.-R. Ruus (eds.), Õppimine mitmest vaatenurgast [Learning from different viewpoints], Acta Universitatis Scientiarum Socialium et Artis Educandi Tallinnensis: A24 Humaniora, Tallinn, TPÜ kirjastus, 2004, pp. 13-33; 
on theoretical-philosophical, substantive, and applied aspects. In general, researchers (Viive-Riina Ruus, Mare Oja, Urve Läänemets, Edgar Krull, Karmen Trasberg, Rain Mikser, Vadim Rõuk, Juta Jaani, Maria Jürimäe, Ene-Silvia Sarv, Vadim Rõuk, etc.) considered Estonian curricular reform as:

- A series of historical events and a political process;

- The process of shaping the foundations and principles of curriculum and of common/shared education values;

- Conceptual change;

- Discursive practice (re-establishment of the discursive subject - Estonian nationality and national education; the emergence of self-determining personality and school, the formulation of a constructivist learning approach); and

- A knowledge creation process. ${ }^{8}$

The concepts of and approaches towards the curriculum development process reveal the existence of various, partly contradictory ideas and options. Rarely is the whole approach to the study of curriculum and its development historical, considering the participants' subjective views, or deal with school level processes.

Approaches to the history of curriculum reform vary in perspective. Cuban $^{9}$ describes $20^{\text {th }}$ century curriculum reforms in the United States as a failed tool for changing student behaviour and knowledge. He notes, however, that the curriculum development process is one of the few in which various groups from democratic communities and societies with differing views and values can debate about their desires for future generations. There are contrasting approaches of research: child growth/upbringing-centred; lawcentred; ${ }^{10}$ standards-outcomes centred; and practice, social regulation and power-centred. ${ }^{11}$

It is important to note that Estonia was the crossing-point of cultures for centuries: German, Northern European/Swedish, Russian and Anglo-American. This influenced educational theory, practice, and curriculum development, especially in the late $20^{\text {th }}$ century. Soviet subject programmes reflected

T. Tenno (ed.), Curriculum Theory, Practice and Active Learning in Changing Societies: the 2nd International Conference, September 12-14, Tartu, University of Tartu, 2002; E.-S. Sarv, Demokraatiast ja humanismist öpetajale: Eesti haridusuuendus - hariduse demokratiseerumine ja humaniseerumine [On democracy and humanism for teachers: Estonian educational innovation - democratisation and humanisation of education], Tallinn, Riiklik Eksami- ja Kvalifikatsioonikeskus, 1997.

${ }^{8}$ E.-S. Sarv, The Learning Organisation and Knowledge Management (LOKM) Model of School and Typology of Estonian Schools, 2005. Available: http://www.leeds.ac.uk/educol.htm (accessed 12.02.20).

9 L. Cuban, 'The Lure of Curricular Reform and Its Pitiful History', The Phi Delta Kappan, vol. 75, no. 2, 1993, pp. 182-185.

${ }^{10}$ D. Tyack, T. James, A. Benavot, Law and the Shaping of Public Education 1785-1954, Madison, University of Wisconsin Press, 1987.

${ }^{11}$ T. S. Popkewitz, 'The Production of Reason and Power: Curriculum History and Intellectual Traditions', Journal of Curriculum Studies, vol. 29, no. 2, 1997, pp. 131-164. 
German Bildung and Didaktik influences as did Soviet pedagogical practices. The formation of Estonian curriculum in the 1980s and 1990s were most influenced by the ideas and work of Estonians Heino Liimets, Johannes Käis; Americans Hilda Taba, John Dewey, and James W. Botkin; ${ }^{12}$ and Soviets Lev Vygotski, Aleksei Leontiev, Vasili Davydov and Daniil Elkonin (developmental teaching). ${ }^{13}$

Curriculum development involves and affects a large number of people. In addition to enthusiasm and innovation, the impact/occurrence of "circulating stereotypes" is highlighted: parents, teachers, and officials expect and reintroduce their experience, despite declaring something else. Sometimes, curriculum development and implementation processes do not lead to an increase in the professionalism of the teacher, as expected. ${ }^{14}$ But new curriculum - development of general competences of students and active teacher participation in school-curriculum development processes - are appreciated/adapted and implemented by $75 \%$ of teachers. ${ }^{15}$

This indicates potential conflict inside the process itself and between curriculum applications and perceptions of the process. These contradictions can differ during various stages of society and curriculum development. Certainly, it is a problem of the reciprocal relationship between an ideal vision and reality.

The main purpose of our paper is to explain and analyse the process of changes and development of curriculum for Estonian general education during the critical period of regaining independence: 1) What is the timeline and what are the key events in the curriculum development process and the substantive divisions? and 2) What is the perception of key events by participants and observers?

Development of the Estonian curriculum should be considered as a whole, starting with the breakthrough in 1987 (ESSR Teacher Congress, expert meetings, basics of curriculum plans and concepts) through to the establishment of a national curriculum in 1996/97 and to this day. Our focus is on 1990-1993, which is sometimes described as "the curricula wars."

12 J. Botkin, M. Elmandjira, M. Malitza, No Limits to Learning: A Report to the Club of Rome, Oxford, Pergamon Press, 1979.

${ }^{13}$ A. Savik, 'Õpilaste iseseisev töö PTUI uurimisprogrammis' [Students' independent work in the research programme of PIPR], Kooliuuenduslane [School Innovator], no. 3-4, 1999, p. 20.

${ }^{14}$ M. Erss, et al., 'Teachers' Views of Curriculum Policy: The Case of Estonia,' British Journal of Educational Studies, vol. 62, no. 4, 2014, pp. 393-411.

${ }^{15}$ E.-S. Sarv, Õpetaja ja kool õpilase arengu toetajana. Õpetaja enesest ja koolist [Teacher and school supporting pupils' development. Teacher about her/himself and about school], Tallinn, Tallinna Ülikool, 2008, p. 91. 


\section{Methodology, research instruments, sources, background and evaluation}

This study is historical, based on analysis of documents, publications, and personal reflections related to curriculum development for Estonian general education. Historical "research includes reconstruction from a holistic perspective of the past to achieve a better or new understanding of events." 16 We use an historical approach in the frame of systems theory ${ }^{17}$ to understand curricula development and experience phenomena. General education curricula is considered the centre of a dynamic system that involves institutions, organisations, persons, activities, and theoretical-paradigmatic aspects related to the curriculum process. Flood points out that the soft systems theory often overlooks the problem of power and social change resulting from the monopolisation of knowledge. ${ }^{18}$ We deliberately take this into consideration.

We suppose that the development story of the curriculum reflects conflicting organisational, theoretical-historical, and implementation views and that at different levels of the system, the perceptions of individuals/actors in the reflection/understanding of the whole process is partial and does not cover the entire system.

Primary sources are documents from the Tallinn University Estonian Pedagogical Archives and Museum, the Estonian National Archives, and interviews, ${ }^{19}$ conversations, notes, and memoirs of curriculum developers and users.

\section{Findings: The story of Estonian national curriculum}

First, we look at the general background of curriculum development. The second part deals with curriculum initiative and development (1987, 1989, 1996). The third part describes five turbulent years of the competing EED curriculum. The fourth part of our findings explores the critical events via personal experiences.

The process of development of the national curriculum cannot be understood without taking into account Soviet-era heritage and the intensive, broad-based process since the Teacher Congress of 26 March 1987. For decades, the ESSR had been the initiator and test site for new education models (e.g. polytechnic instruction, in-depth subject classes and schools, specialised classrooms with

${ }^{16}$ L. Cohen, L. Manion, K. Morrison, Research Methods in Education, London, Routlege Falmer, 2000.

${ }^{17}$ A. J. Romiszovski, 'Systems Approach to Design and Development', in T. Husen, T. Neiville Postlethwaite (eds.), The International Encyclopaedia of Education, New York, Elsevier Science, 1994, pp. 5895-5901.

${ }^{18}$ R. L. Flood, Rethinking the Fifth Discipline: Learning within the Unknowable, London, Routledge, 1999 , p. 60.

19 Seven people were interviewed from 2011 to 2015. Inge Unt, Viive Riina Ruus (1936-2018), Ene-Mall Vernik-Tuubel, Mari Kadakas, Sulev Valdmaa, Ants Eglon and Väino Rajangu, interviews by Vadim Rõuk and Rain Mikser. Personal archives of Vadim Rõuk. 
equipment for teaching a particular subject, remedial classes, etc.). ${ }^{20}$ Teacher Research Courses, PIPR, ${ }^{21}$ and regular lifelong professional development ${ }^{22}$ had created a basis for the emergence and implementation of new ideas. In the particularly intensive early years of Estonian education renewal, more than 1000 people were actively involved in the design and development of national education $^{23}$ - teachers, methodologists, researchers, and officials. They were assisted by at least 5000 people who participated in major teacher and educator forums and were involved at the school level. ${ }^{24}$

The dramatic nature of the changes and how they were perceived can be illustrated with two examples.

First, on 11-12 May 1988, the 'Pedagogical Science for Educational Innovation' seminar was organised by the steering group for educational reform. Representatives of the USSR Pedagogical Academy and other institutions participated. The terms "subject schizophrenia" and "subject idiotism" were used to describe the system and existing study plans, syllabi, and teaching paradigm. Even ten years later, teachers recalled the 1987 Congress and the Seminar as top-experiences - a personal paradigm change. ${ }^{25}$

Second, in the Chronology of Estonian School and Pedagogy, ${ }^{26} 15$ events are mentioned in 1987 such as the $300^{\text {th }}$ performance of the most favourite musical for children. However, events absent were the Teacher Congress on 25-26 March, reform concept-oriented expert meetings, a think-tank in May, curriculum and reform plans competition in June, etc. ${ }^{27}$ Professor Unt reminisced: "A real

${ }^{20}$ I. Kestere, et al., 'Schools of General Education,' in I. Kestere, A. Kruze (eds.) History of Pedagogy and Educational Sciences in the Baltic Countries from 1940 to 1990: an Overview, Riga, RaKa, 2013.

${ }^{21}$ PIPR - Public Institute of Pedagogical Research - was established at the State Teacher InService/Professional Development Institute in 1972 and replaced Teacher Scientific Research Courses (seminar) Ühiskondlik Pedagoogika Uurimise Instituut (ÜPUI). STPDI (VÕTI) - State Teacher In-Service Training Institute, or State Teacher Professional Development Institute.

22 Teacher professional development had special 4-week courses for teachers with various pedagogical experience: pedagogy (3-5 years of pedagogical experience), psychology ( 10 years), subject area ( 15 years), advanced pedagogical and psychological studies (20 years or more). The courses were organised by STPDI.

${ }^{23}$ E.-S. Sarv, 'Tegevused' [Activities], in Demokraatiast ja humanismist ópetajale: Eesti haridusuuendus - hariduse demokratiseerumine ja humaniseerumine [On democracy and humanism for teachers: Estonian educational innovation - democratisation and humanisation of education], Tallinn, Riiklik Eksami- ja Kvalifikatsioonikeskus, 1997, pp. 56-60.

${ }^{24}$ Numbers are based on journals, registration lists, etc. held by the Ministry of Education or others institutions that organized the forums.

25 E.-S. Sarv, Muutused hariduses 1985. aastast tänapäevani. Üliópilasprojekt [Changes in education from 1985 to today. Student research project], Narva, TÜ Narva Kolledž, 2012. Available: https:// www.scribd.com/doc/147151808/Muutused-hariduses-1985-tanapaevani-UliopilasprojektToim-E-S-Sarv (accessed 20.02.20).

${ }^{26}$ H. Rannap (ed.), 'Eesti kooli ja pedagoogika kronoloogia' [Chronology of Estonian school and pedagogy], 2002/2012. Available: https:/pdfslide.net/documents/eesti-kooli-ja-pedagoogikakronoloogia.html (accessed 20.02.20).

${ }^{27}$ See Introduction of this volume, and E.-S. Sarv, 'Tegevused' [Activities], in Demokraatiast ja humanismist õpetajale: Eesti haridusuuendus - hariduse demokratiseerumine ja humaniseerumine 
sense of excitement arose after the congress and brainstorming sessions were organised: seminars, gatherings, the whole innovation so far was gathered." ${ }^{28}$

New national and subject curricula were created in 1987-89, but reforms were under attack by opposition in the ESSR and Moscow. To support Estonian school sovereignty, the Estonian Education Platform ${ }^{29}$ was created and presented at the USSR Congress of Educators in Moscow in 1988. It identified the basics for educational reform: 1) democratisation of educational organisation, 2) humanisation of education content, and 3) value of education. Study programs would be structured as curriculum-type programs, providing for student-teacher collaboration and active involvement of all actors in education and educational decision-making.

This period and the first years of independence encouraged various ideas and increased information gathering, including scientific-philosophical educational literature and contacts with foreign specialists. This led to controversial and even conflicting developments in the conception and development of general education curricula.

\section{The development of Estonian National Curriculum}

From 1984 to regaining independence 1991, major changes included: ${ }^{30}$

1984 - change to 12-year general education;

1987 - national school and curricula developments and changes; ${ }^{31}$

1989 - first version of national subject curricula published; and

1989-1991 - further development of curricula, especially in "sensitive" subjects such as history.

After regaining independence in 1991:

1991-1993 - competing curricula projects ("curricula wars");

1996 - adoption of the National Curriculum; and

2002 - new version of National Curriculum. ${ }^{32}$

[On democracy and humanism for teachers: Estonian educational renewal - democratisation and humanisation of education], Tallinn, Riiklik Eksami- ja Kvalifikatsioonikeskus, 1997, pp. 56-60.

${ }^{28}$ Inge Unt, interview by Vadim Rõuk, March 3, 2011. Personal archives of Vadim Rõuk.

${ }^{29}$ E. Kareda, et al., Eestimaa haridusplatvorm [The Education Platform], Tallinn, Teacher InService Institute, 1989, pp. 11-15. The Education Platform was prepared for the representation of the reform of the Estonian general education (school-experiment) at the USSR Teachers' Congress in 1988 as the platform for the ESSR delegation in Moscow. It was also published in Russian and was distributed at the All-Union onferences in 1988-1990.

${ }^{30}$ V.-R. Ruus, E.-S. Sarv, 'Curriculum Reform as a Challenge to Teacher Identity and Professionalism (the Estonian Case), paper presented at European Education Research Association (EERA), Helsinki, Finland, 25-27 August 2010.

${ }^{31}$ P. Lepik, M. Remmel, E.-M. Vernik, 'Mõttetalgud üldhariduse harimiseks. I vooru reproduktiivne kokkuvõte' [Think tank - expert meeting to educate general education, Reproductive summary of the 1st round], Nõukogude Õpetaja, [Soviet Teacher], 29 May 1987.

32 V.-R. Ruus, 'Eesti õppekavareform 1987-2002' [Curriculum reform 1987-2002 in Estonia], in A. Liimets, V.-R. Ruus (eds.), Õppimine mitmest vaatenurgast [Learning from different 
We will briefly discuss the initial stages of curriculum development (19871990) as it is necessary to understand further development. The focus will be on the emergence of two curriculum models from 1990-1993.

1987 - Estonian national curriculum initiative. The Estonian Teachers' Congress on 25-26 March provided the formal basis for reforming education and establishing the Estonian National School. Meetings and brainstorming sessions were led by a steering team ${ }^{33}$ in May and June. The main features of the new national curriculum projects were designed and evaluated through public competitions: on 22-23 June 1987, nearly 400 people evaluated the projects.

The Institute for Pedagogical (Scientific) Research ${ }^{34}$ project was selected for further development, and many other projects were used later. ${ }^{35}$ One participant noted: “... when this Midsummer Day ended, people were in tears; everyone stood up, hugged and clapped, it was such a [unifying event]." ${ }^{36}$ At the same time, volunteer groups were set up to create new syllabi for school subjects, involving a large number of active teachers. By 8 July 1987, a study plan project and explanatory notes were published.

The new school structure was originally based on the model $5+5+2,{ }^{37}$ but in August, a 3+3+3+3 model was established on which the national curriculum of 1996 was based (still valid in 2019). Russian-language schools were also involved in school reform: transition from the universal Soviet 10-year model to an 11- and later 12-year school using Estonian textbooks and programs.

The project gave schools a great deal of freedom in their own curriculum development, so self-management of schools became important. The creation of school curriculum was finalised in the 1996 curriculum and in the Basic Schools and Upper Secondary Schools Act, revealing parallel curricular processes at the school and state level.

In 1987/88, the planning of subjects, textbooks, programs, and curricula paralleled work on the conceptual background of educational reform. Cautious attitudes towards the innovations emerged from academia, the Communist

viewpoints], Acta Universitatis Scientiarum Socialium et Artis Educandi Tallinnensis: A24 Humaniora, Tallinn, TPÜ kirjastus, 2004, pp. 13-33.

33 The steering team included Education Minister Elsa Gretchkina and Academy of Pedagogical Sciences of the USSR member Heino Liimets, and representatives of various institutions.

${ }^{34}$ Institute of Pedagogical (Scientific) Research of ESSR - IPR (PTUI in Estonian)

35 V.-R. Ruus, 'Eesti õppekavareform 1987-2002' [Curriculum reform 1987-2002 in Estonia], in A Liimets, V.-R. Ruus (eds.), Õppimine mitmest vaatenurgast [Learning from different viewpoints], Acta Universitatis Scientiarum Socialium et Artis Educandi Tallinnensis: A24 Humaniora, Tallinn, TPÜ kirjastus, 2004, pp. 13-33; A. Telgma, 'Eesti NSV Pedagoogika Teadusliku Uurimise Instituut 1959-1991' [The Institute for Pedagogical Scientific Research 1959-1991], Kooliuuenduslane [School innovator], no. 1, 1999, p. 18.

${ }^{36}$ Ants Eglon, interview by Vadim Rõuk and Rain Mikser, January 22, 2015. Personal archives of Vadim Rõuk.

37 This meant 5 years primary +5 years basic +2 years secondary education. Until 1988 in Russia and most Soviet republics, the full general education cycle was $8+2$, in Estonia and Lithuania $11(8+3)$ years. 
party, and some educational institutions. Nevertheless, cooperation with progressive educational forces in the Baltic republics and Moscow was so strong that attempts to stop the school experiment remained formal. ${ }^{38}$ ESSR Minister of Education Gretchkina issued directives on the implementation of the school experiment in June 1988, and on 1 September $1988,{ }^{39}$ a new and fundamentally different study plan was introduced by 21 schools (Grades 1-12) and by most other schools in 1989.

The drivers of this effort were STPDI and SIPR methodologists. As Kadakas recalls: "The project for the experimental study plan of the Estonian SSR General School was published in Soviet School, but the authors were not mentioned. That was the subject of the general debate. For SIPR, there were ... syllabus working groups that re-organised existing syllabi ... according to the principles of the new study plan and the prescribed volume of subject studies." ${ }^{20}$ General design of the curriculum took place at SIPR until its liquidation in 1991 and then at Tallinn Pedagogical University. According to Unt, eradication of the Institute was "a very foolish decision that was regrettable." ${ }^{41}$

1989 experimental and the 1996 National curriculum. In 1989, a pilot version of the experimental curriculum ${ }^{42}$ was developed by SIPR.

The 1989 experimental curriculum gave schools the freedom to determine their own academic specialty (30\% of studies at the secondary level); introduce new subjects in curriculum (such as social studies and health education); decrease of the amount of sciences, math, and Russian-language lessons; increase modern languages and fine arts studies; rid lessons of communist ideology; eliminate "production studies"; introduce a 5-day week (instead of the previous 6 days); and place emphasis on personality development and national cultural values. ${ }^{43}$

The curriculum provided compulsory common content and four branches of the school's choice - general, humanitarian, sciences and economictechnical - as well as methodological expectations. But the study materials were still from the Soviet-era and imbued with Soviet ideology.

${ }^{38}$ The management of education was consolidated under perestroika - instead of two separate ministries and the Vocational Education Committee, one institution was formed the Committee of Education of ESSR. There was uncertainty about the commitment of new structures and ministers in the National school and curriculum process.

39 'Haridusuuenduse dokumendid ja märkmed 1987-1989' [Documents and papers on educational renewal 1987-1989]. Personal archives of Ene-Silvia Sarv.

${ }^{40}$ Mari Kadakas, interview by Vadim Rõuk, March 17, 2014. Personal archives of Vadim Rõuk. Some subject groups were worked on by STPDI or had two parallel developer-groups (physics, for example), and created a new syllabus and content.

${ }^{41}$ Inge Unt, interview by Vadim Rõuk, March 25, 2011. Personal archives of Vadim Rõuk.

${ }^{42}$ Curriculum, Tallinn, Ministry of Education ESSR, 1989. In each following year, the books on methodological guidelines and recommendations were published.

${ }^{43}$ V.-R. Ruus, E.-S. Sarv, 'Curriculum Reform as a Challenge to Teacher Identity and Professionalism (the Estonian Case), paper presented at European Education Research Association (EERA), Helsinki, Finland, 25-27 August 2010. 
SIPR researchers prepared a research and development project for a prospective curriculum for General Education (up to 2000), which was discussed and negotiated at various meetings. ${ }^{44}$ The Ministry of Education recognised it as a priority. ${ }^{45}$

Despite confrontation and criticism, the National Curriculum was completed and introduced in 1996 instead of 2000. The most important aspects were the holistic vision of Estonia as a democratic and market-based infosociety: broad content units organising curriculum content in parallel with subjects and study courses; introducing competencies for defining learning outcomes: introducing cross-curricular themes; and emphasis on permanent change and development of personality, society, and curriculum. ${ }^{46}$

Researchers ${ }^{47}$ underlined the freedom and responsibility of schools to specify learning content and determine the number of lessons within the frame set by the National Curriculum. New subjects were introduced - health education and human studies, philosophy, psychology, and family education. Gymnasium subjects were recast as courses (each course equalling 35 lessons). Schools were expected to develop competency-based integrated curricula.

The 1996 curriculum was generally well received (Finnish Ministry of Education, 1999, ${ }^{48}$ OECD Education Policy Group, 2001 ${ }^{49}$ ) as a contemporary socio-constructivist curriculum.

ECDE curriculum 1992, 1993; Turbulent years 1989-1993. STPDI was reorganised as the Estonian Centre for Development of Education ${ }^{50}$ (ECDE) in 1989, but the statutes did not directly anticipate study of the curriculum. In 1991, the Institute for Pedagogical Research, the ECDE, and the Ministry's General Education Department were charged with providing new versions of the curriculum by the end of 1992. The opportunity to design holistic curriculum documents instead of separate subject syllabi ('programmes' in

${ }^{44}$ Commission members: I. Unt, G. Karu, J. Orn, U. Läänemets, V. Ruus, A. Eglon.

${ }_{45}$ 'Eesti Vabariigi HM juures töötava teaduskomisjoni koosoleku protokollid' [Minutes of the meeting of the Scientific Committee of the Ministry of Education of the Republic of Estonia], 1990-1999, Tallinn University Estonian Pedagogical Archives and Museum, K0042572, p. 4.

${ }^{46}$ V.-R. Ruus, E.-S. Sarv, 'Curriculum Reform as a Challenge to Teacher Identity and Professionalism (the Estonian Case), paper presented at European Education Research Association (EERA), Helsinki, Finland, 25-27 August 2010.

${ }^{47}$ U. Läänemets, 'Content Development for Estonian General Comprehensive Schools: Context, Curricula and School Practice 1991-2016', in Education Reform in Comprehensive School: Education Content Research and Implementation Problems, Rezekne, Rezekne Academy of Technologies, p. 56. Available: http://journals.rta.lv/index.php/PSPI/article/view/2182 (accessed 20.02.20)

${ }^{48}$ Hinnang Eesti õppekavale. Kokkuvõte õppekava üldosa ja ainekavade tugevatest ja nõrkadest külgedest [Evaluation of Estonia's curriculum. Summary on strengths and weaknesses of the general part and subject syllabi], Opetushallitus, 1999. Available: http://www.curriculum. ut.ee/sites/default/files/sh/soome_hinnang_eesti_6ppekavale.pdf (accessed 10.01.13).

${ }^{49}$ Riiklike hariduspoliitikate ülevaated, Eesti [Reviews of National Policies for Education, Estonia], OECD, 2001, pp. 17, 24. Available: http://digar.nlib.ee/show/nlib-digar:9588 (accessed 13.07.17).

${ }^{50}$ 1989-1993, EHA in Estonian. 
the Soviet era) was immediately seized by the SIPR. Following reorganisation of the institutions, a new type of document in which the authors - all specialists in their respective subjects - made extensive use of research in the field of curriculum theory and practice. ${ }^{51}$

The major change in the renewed curriculum for nine-year basic education was the introduction of a general, explanatory part that reflected ideas pertaining to all subject syllabi. ${ }^{52}$

ECDE specialists compiled the 1992 and 1993 curricula. ${ }^{53}$ The main aim was to support and organise the work of teachers and issue streamlined methodological guidelines. Subjects strongly influenced by ideology, such as history and literature, experienced vast changes and new guidelines. The Basic School Curriculum (ECDE, 1992) was an attempt to include pre-primary and basic education into one curriculum.

The Curriculum for Secondary School, published in 1993, defined compulsory common elements for all secondary education institutions ${ }^{54}$ and stressed that any curriculum is a social agreement between teachers and the general public. Only in a few subjects were two parallel syllabi presented, and alternative, collectively syllabi were rarely mentioned. The physics ${ }^{55}$ syllabus noted that it was an alternative to the Physics Base Program prepared by the School Physics Association. ${ }^{56}$ The 1993 Curriculum attempted to be suitable but was clearly still Soviet in its subject-centred orientation. Broader goals for pupil personal development were addressed in only some subject programmes.

${ }^{51}$ U. Läänemets, 'Content Development for Estonian General Comprehensive Schools: Context, Curricula and School Practice 1991-2016', in Education Reform in Comprehensive School: Education Content Research and Implementation Problems, Rezekne, Rezekne Academy of Technologies, p. 56. Available: http://journals.rta.lv/index.php/PSPI/article/view/2182 (accessed 20.02.20).

${ }^{52}$ E. Krull, R. Mikser, 'Reflection of Cross-Curricular Ideas in the Estonian Curricula of General Education: An Historical Study', TRAMES, vol. 14, no. 1, 2010, p. 44.

${ }^{53}$ I. Unt, U. Läänemets (eds.), Põhikooli öppekava [Curriculum for basic schools], Tallinn, Eesti Hariduse Arenduskeskus, 1992; I. Unt, U. Läänemets (eds.), Keskkooli õppekava [Curriculum for secondary schools], Tallinn, Eesti Hariduse Arenduskeskus, 1993.

${ }^{54}$ I. Unt, U. Läänemets (eds.), Keskkooli õppekava [Curriculum for secondary schools], Tallinn, Eesti Hariduse Arenduskeskus, 1993, p. 1.

${ }^{55}$ O. Eenmaa, V. Paju, 'Füüsika' [Physics], in I. Unt, U. Läänemets (eds.), Keskkooli óppekava [Curriculum for secondary schools], Tallinn, Eesti Hariduse Arenduskeskus, 1993, pp. 44-45.

${ }^{56}$ E. Pärtel, K. Timpmann, H. Voolaid, Üldhariduskooli programmid. Füüsika. Kontseptsioon ja programmid 8.-12. klassile [Programmes/syllabi for general education. Physics. Conception and programmes for grades 8-12], Tallinn, Eesti Ôppekirjanduse Keskus, 1991, pp. 25-31. These syllabi were designed according to prospective curriculum (and number of lessons) of PTUI 1987 and 1989/90 curricula projects. It is crucial to understand that the School Physics Association created a national concept and intended to create all kits for independent Estonian education (a revolutionary way supported by a large number of teachers and researchers involved). Other approaches intended to use former Soviet concepts and kits for as long as needed. 


\section{Critical periods and events - experience in interviews}

The overall goal of curriculum change was to reform the educational reality. The quality of reforms, from the point of view of the school environment, is perceived by the performers. Heinla points out that in retrospect, most school directors recalled the 1980s and 1990s as a period of self-determination and great freedom, accompanied by increasingly restrictive regulations: "The best years were 1988-1992 when schools were free to decide on their own." ${ }^{27}$ A similar perception emerged in all teacher interviews: at that time, there was freedom to choose methods and adapt learning, although the inappropriateness of textbooks created discomfort. ${ }^{58}$

Mari Kadakas, who was involved in curriculum review noted:

The renewal of the curriculum really started in 1991 and was planned in stages. Great plans for nearly 10 years.... at that time, it was strange to people ... such a long time for this curriculum. In our working groups there were subject-specialists, ... school representatives, representatives of higher education institutions, all bundled together. Certainly, there were over 200 of them ... the general goals of learning and education/ upbringing. Interestingly, they were not from the teacher's point of view ... but from the pupil's point of view: as a result of his/her studies ... how to behave, etc. Then there were curriculum principles that were not previously formulated ... Why did we do this [in SIPR since 1987]? ... we did not have to, but we just were interested in this school-innovation. ... this was a purely voluntary thing. ${ }^{59}$

Viive-Riina Ruus noted the sense of responsibility of the task:

In 1989, we did not have any initial tasks ... we started ourselves, we did it ourselves, we wanted to have a sovereign curriculum in Estonia. ... It was clear that foreign language teaching needed to be reinterpreted, schools needed to be more autonomous ... we also got Saturday free ... It was very important that we had a more general way of thinking, rather than subject-centred. ... And imagine ... from 1987 to 1989, it was two years for the completion of a transitional curriculum through volunteer work. ... I would say in this way that the development process of the curriculum actually was developing society broadly, or we say that it was a school of democracy, it was indeed a school of

57 E. Heinla, 'Üldhariduskoolide direktorite nägemus õpetajate, lapsevanemate ja õpilaste otsustamisvõimalustest koolielus' [Viewpoints of directors of General Education Schools on the decision-making rights of teachers, parents and students in school life], in E.-S. Sarv (ed.), Osalusdemokraatia toimimisest Eesti üldhariduses [The functioning of participatory democracy in general education in Estonia], Tallinn, Tallinna Ülikooli kirjastus, 2008, p. 28.

58 E.-S. Sarv, Muutused hariduses 1985. aastast tänapäevani. Üliõpilasprojekt [Changes in education from 1985 up to today. Student research project], Narva, TÜ Narva Kolledž, 2012. Available: https://www.scribd.com/doc/147151808/Muutused-hariduses-1985-tanapaevaniUliopilasprojekt-Toim-E-S-Sarv (accessed 20.02.20)

59 Mari Kadakas, interview by Vadim Rõuk, March 17, 2014. Personal archives of Vadim Rõuk. 
reflection-democracy, although at that time we could not yet use such a name. Secondly, it raised the feeling of being involved with teachers. They were responsible for this. ${ }^{60}$

In her interview, ${ }^{61}$ Unt took a positive view of these changes and emphasised their connection with the work and aspirations of long time education minister Eisen and academician Liimets. One of the curriculum authors, Valdmaa, said: "It was a well-organised process and it was not possible to isolate curriculum makers in such a way that who did the general part and who did the syllabus, it was a rather synthetic thing, and I would say that Urve Läänemets, who built the whole system, actually trained a number of people in this process to understand what the curriculum is about." 62

Ants Eglon noted some disconnects: "ECDE requests were related to some incomprehensible ambitions, which essentially separated them from the schools, which in turn created a kind of 'hole' in educational renewal... ${ }^{63}$

Viive-Riina Ruus described the difficulties:

At that time, we did not have literature that we all could now investigate. There were really poor brochures [in Russian] that provided an overview of education in this or that country. They were so small; frankly, there was nothing to find. So, we were forced to think about these things ourselves. ... And I thought - how could we cope so well? ${ }^{64}$

So, at the beginning of Estonian independence were three National Curriculum experimental projects and schools experienced the freedom to create school-curriculum.

\section{Discussion and summary: development of the curriculum}

The development of the curriculum reflects somewhat contradictory views on individual levels of the system and in the perception of individuals: the reflection of the whole process may reveal partial understanding that did not cover the entire process.

The development of curricula in Estonia (1987-2004) can be summarised in the schematic diagram shown in Diagram 1.

\footnotetext{
${ }^{60}$ Viive-Riina Ruus, interview by Vadim Rõuk, March 24, 2014. Personal archives of Vadim Rõuk.

${ }^{61}$ Inge Unt, interview by Rain Mikser, June 13, 2014. Personal archives of Vadim Rõuk.

${ }^{62}$ Sulev Valdmaa, interview by Vadim Rõuk, March 17, 2014. Personal archives of Vadim Rõuk.

${ }^{63}$ A. Eglon, 'Eesti kooliuuenduse kujunemisest' [On formation of Estonian school innovation], manuscript, Tallinn University Estonian Pedagogical Archives and Museum, K43010-3, p. 8.

${ }^{64}$ Viive-Riina Ruus, interview by Vadim Rõuk, March 24, 2014. Personal archives of Vadim Rõuk.
} 
Diagram 1. Curriculum Development 1987-2004

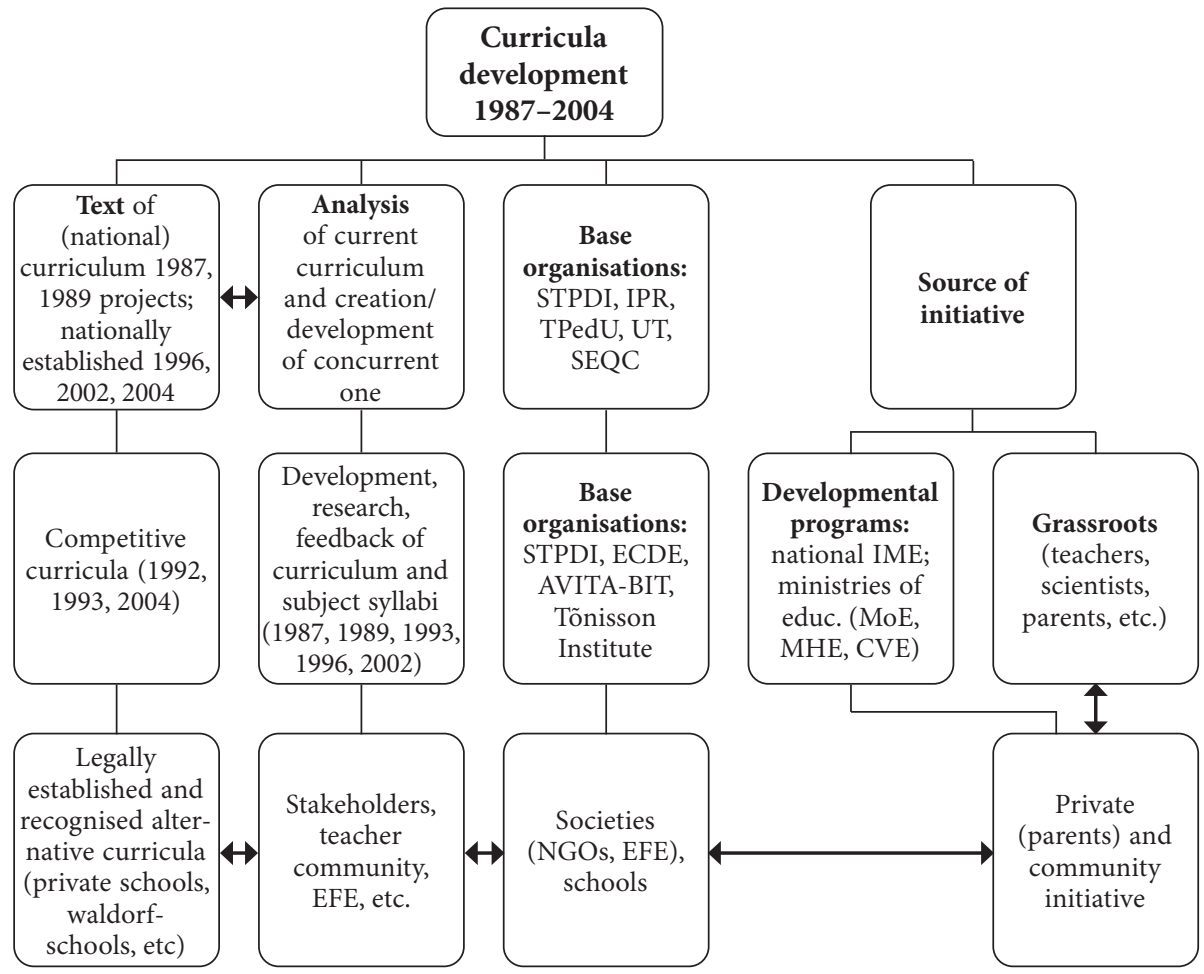

Objective versus subjective. Krull's comprehensive analysis ${ }^{65}$ considers the Soviet curriculum from 1944 to 1991 without mentioning the comprehensive reform that began in 1987.

Krull does note post-Soviet reforms ${ }^{66}$ and the ECDE's reliance on Taba's ideas in curriculum development. The speed of curriculum development and willingness to maximize access to existing systems and materials can be explained by its contrast with the IPR curriculum and previous broad-based curriculum development.

The root causes of the "curricula wars" in the first half of the 1990s and subsequent friction could be found in the 1987-1989 renewal process. The initiators and their supporters were largely motivated to move forward with joint activities and perceived freedom and creativity, all the more so because in

${ }^{65}$ E. Krull, 'Õppekavaülesed ideed Eesti õppekavades' [Cross-curricular ideas in curricula of Estonia], Haridus [Education], no. 11-12, 2009, pp. 34-41.

${ }^{66}$ E. Krull, 'Hilda Taba (1902-1967),' UNESCO. International Bureau of Education. Prospects, vol. 33, no. 4, 2003, pp. 481-491. Available: http://www.ibe.unesco.org/sites/default/files/tabae. pdf (accessed 27.05.18); H. Taba, Curriculum Development: Theory and Practice, New York, Harcourt, Brace \& World, 1962. 
schools and several subject areas, reform was launched on the basis of new subjects, new assessment, syllabi, study materials, etc.

Estonian education ministers were also part of this dilemma. In his interview, the then Chairman of the Educational Committee Väino Rajangu noted that there were no qualified creators of curriculum in Estonia during the transition period. Therefore, is seemed logical to delegate the activities of some of the actors to others who were, perhaps, better. ${ }^{67}$

Here, we see distrust towards collective knowledge and knowledgecreation $^{68}$ and the search for expert judgment and underestimation of democratic, grassroots level participation in favour of top-down governance.

In 2001, the majority of Estonian education ministers, who were asked to highlight five of the most important educational issues, attended a conference dedicated to the opening of the Faculty of Education at the University of Tartu. ${ }^{69}$ All of them noted curriculum as one. However, they were divided in defining the problem. Some considered the 1996 curriculum (especially its general part) to be a very good and big step as it decoupled learning from the USSR curriculum to reach a new paradigm. Others referred to the entire curriculum development process since 1987 as a continuation of the USSR curriculum.

Contextual-conceptual. The first years of education reform after the 1987 Teachers Congress were years of searching for a way, a path. The initial ideas of change and their specifics were aimed at the (re)establishment of a national school.

The original curriculum plans ${ }^{70}$ included the conceptual foundations of the educational process and democratisation of school. Conceptual innovations and implementation ideas were also reflected in the works of the 1988 Competition for Education Innovation Programmes. Although only some of the programmes were published, ${ }^{71}$ several years later they definitely promoted the views of compilers and readers. As Ruus noted ${ }^{72}$ about creating a national

${ }^{67}$ Väino Rajangu, interview by Vadim Rõuk, April, 2015. Personal archives of Vadim Rõuk.

${ }^{68}$ I. Nonaka, H. Takeuchi, The Knowledge-Creating Company: How Japanese Companies Create the Dynamics of Innovation, New York, Oxford University Press, 1995.

69 'Eesti hariduse viis probleemi' [Five problems of Estonian education], in Tartu Ülikooli haridusteaduskonna avamisele pühendatud konverentsi ettekanded 1. septembril 2001. a [Conference devoted to the opening of the Faculty of Education at the University of Tartu on 1 September 2001], Tartu, Tartu Ülikool, 2002.

${ }^{70}$ E. Gretchkina, H. Liimets (eds.), Na puti k novoi shkole I: shkola Estonskoi SSR v obnovlenii [On the way to a new school I: the school of ESSR in renewal], Tallinn, ENSV Haridusministeerium, ENSV Pedagoogika Teadusliku Uurimise Instituut, 1987.

${ }^{71}$ E.-M. Vernik (ed.), Eesti NSV haridusuuenduse programmide ja stsenaariumide konkursi töid I [Work of the Estonian SSR Educational Innovation Programmes and Scenario Competition, I], Tallinn, ENSV Riiklik Hariduskomitee, 1989; K. Kaldma (ed.) Hariduse uuendamise võimalusi Eesti koolis. Haridusuuenduse konkursi töid, [Opportunities for renewal of education in Estonian school. Work of the competition for educational innovation], Tallinn, Haridusministeerium, 1991.

${ }^{72}$ V. Ruus, 'Eesti üldkooli perspektiivse õppekava üldalused' [Principles of the perspective curriculum of Estonian General School], 1992, manuscript, Tallinn University Estonian Pedagogical Archives and Museum, K45089-3, pp. 9, 17. 
school through new concepts, new qualities and general and special competences were introduced. Conceptual differences appeared in the 1992, 1993, and 1996 curricula: curriculum and syllabi were focused on teaching or on learning.

Although several aspects of the process can be viewed negatively, further development and performance of the curriculum model was indisputable. It was a long-term, tactical choice, and not just a curriculum war.

Jaani approved of the approach based on the national curriculum: according to Estonian and foreign experts, the 1996 Curriculum continued to express modern educational ideals. It was in line with the educational strategy 'Learning Estonia' and supported the ideal of a global learning society and emphasis on general skills. The values highlighted in the 1996 and 2002 curricula deserve to be continued in the future. ${ }^{73}$

The fast-changing era for curricula was commented on by Hunkins and Hammill:

Arguing about getting beyond Tyler and Taba is not so much to criticize their work and their era as it is to recognise that we are in different times - times that challenge us to think in novel ways about our realities and how to generate curricula within them. Tyler and Taba reflected a view of modernism: life could be viewed as mechanical and there existed a stable-state universe, the process of curriculum development could be compartmentalized and decontextualized, and goals could be separated from the experiences designed to address those goals. ${ }^{74}$

Although confrontation demanded energy that could have been used more rationally, its positive aspect was also acknowledged: it forced the process of development of national curriculum and considered and reasoned thought about each step. ${ }^{75}$

\section{Conclusion}

The field of education from 1989 to 1993 and further - from an organisational, substantive, and political viewpoint - passed through turbulent times. ${ }^{76}$ Participants in and critics of the curriculum process accumulated knowledge from previous years of innovation: grassroots and intermediate level support and educational associations emerged and thrived.

One consequence of the Soviet period was the lack of professional expertise in the field of curriculum because of Soviet political centralism. There were

${ }^{73}$ J. Jaani, 'Õppekavakogemus õpetab’ [Curriculum-experience gives a lesson], Haridus [Education], no. 11, 2004, p. 14.

${ }^{74}$ F. P. Hunkins, P. A. Hammill, 'Beyond Tyler and Taba: Reconceptualising the Curriculum Process,' Peabody Journal of Education, vol. 69, no. 3, 1994, p. 10. Available: http://group4 edci7334curriculmanddevelopment. pbworks.com/w/file/fetch/89838671/Beyond\%20Tyler\%20 and\%20Taba\%20(1).pdf (accessed 10.07.17).

75 Viive-Riina Ruus, interview by Vadim Rõuk, March 24, 2014. Personal archives of Vadim Rõuk.

76 The vortex-metaphor was used by V.-R. Ruus in her year 2000 writings to characterize this time. 
exceptions such as mathematics textbooks for Estonian schools that existed since the 1970s. This facilitated the creation of syllabi and teaching materials for autonomous Estonian schools. However, the general ideology and groundwork for the national curriculum was laid between 1987 and 1988.

In the 2000s, curriculum application studies and their interpretations showed a divergence in the evaluation of curriculum and the quality of its development. ${ }^{77}$ This shows that contradictions were and are truly deep and lasting. In some research, ${ }^{78}$ discussion of the process of curriculum development is limited and the 1987 and 1989 projects are ignored. This may be due to inadequate or selective coverage of developments during that period.

By 1991, schools could use the experimental curriculum of 1989/90 and had control of school leadership and teachers.

The step-by-step establishment of the National Curriculum was based on contemporary studies and on collective knowledge and ideals of the educational community. The latter included reform year experience of schools and teachers, Estonian education heritage, and feedback. The initiative of many schools and teachers in shaping curricula and syllabi should be stressed, including the creation of alternative and private schools.

Reflections on the curriculum process at the beginning of the $21^{\text {st }}$ century show significant discrepancies: readers interpret texts differently because of differing pedagogical paradigms and perspectives on "good and right education."

These inconsistencies appeared during the curriculum-creation period and were amplified during continuous institutional restructuring. This prolonged process consumed much spiritual strength, time, and money. Yet, the existence of an "opponent" forced the other side to try, analyse, and claim merits and is believed to have improved the quality of the documents. The process of developing a curriculum is a historical, ideological, and symbolic struggle in Estonia. The question remains, how could compromise and commonality between different paradigms be found, and would finding such be possible?

From a historical perspective, the period 1989-1993 was a period of turbulence, characterized by the simultaneous presence of and competition between opposing and contradictory applications and pedagogical and curriculum concept views and paradigms, which were not well understood by the various groups. The school level was characterized by an increasing disagreement between progressive, self-assured and cautious, conservative schools and Estonian and Russian-language schools.

\footnotetext{
77 E. Krull, K. Trasberg, Changes in Estonian General Education from the Collapse of the Soviet Union to EU Entry, University of Tartu, Faculty of Education, 2006. Available: https://files.eric.ed.gov/ fulltext/ED495353.pdf (accessed 10.07.17).

${ }^{78}$ For example: E. Krull, R. Mikser, 'Reflection of Cross-Curricular Ideas in the Estonian Curricula of General Education: An Historical Study, TRAMES, vol. 14, no. 64/59, 2010, pp. 34-53; M. Lees, 'Estonian Education System 1990-2016: Reforms and Impact.' Available: http://4liberty.eu/wpcontent/uploads/2017/04/Mihkel-Lees_Estonian-Education-System-1990-2016_Reforms-andImpact_Review-6.pdf (accessed 10.07.17).
} 
Finally, it is appropriate to take a small leap to 2017 when the PISA report ${ }^{79}$ was published, showing Estonia's high ranking. Ruus stated: "This shows that already at that time, we chose the right direction in principle." 80 After reading his interview, Eglon wrote: "It was still a very difficult and confusing time when you had to fight every day for anything and on a broad front. I am glad that we were able to bring general education in Estonia from socialism to today rather well." ${ }^{\prime 1}$

The turbulence of the ideas and power struggle of the transition decade forced people and organisations to learn quickly. The turbulence of openness, innovation, and traditions in the 1980s and 1990s created Estonian independent national education and curricula and was the foundation for $21^{\text {st }}$ century curriculum and school development.

${ }^{79}$ G. Tire, et al., PISA 2015 Eesti tulemused [PISA 2015 results of Estonia], SA INNOVE. Available: https://www.innove.ee/wp-content/uploads/2017/11/PISA-2015_EESTI_ARUANNE_FINAL. pdf (accessed 20.02.20); Estonia in the spotlight. PISA 2015. Available: https://www.innove.ee/ wp-content/uploads/2018/03/PISA_ENG_2015_voldik_web_final.pdf (accessed 15.04.20)

${ }^{80}$ Viive-Riina Ruus, conversation record file, February 10, 2017. Personal archives of Ene-Silvia Sarv.

${ }^{81}$ Ants Eglon to Vadim Rõuk, letter November 12, 2015. Personal archives of Vadim Rõuk. 